\title{
Differing energy densities with laser 670 nm InGaP controls inflammation and collagen reorganization in burns
}

\author{
Luis Angelo Ozan Maligieri ${ }^{a}$, Lia Mara Grosso Neves ${ }^{b}$, \\ Driele Talita de Morais ${ }^{a}$, Rayane Ferreira Domingues ${ }^{a}$, \\ Andrea Aparecida de Aro ${ }^{a}$, Edson Rosa Pimentel ${ }^{c}$, \\ Maria Esméria Corezola do Amaral ${ }^{a}$, \\ Marcelo Augusto Marretto Esquisatto ${ }^{a, *}$, Gláucia Maria Tech dos Santos ${ }^{a}$, \\ Fernanda Aparecida Sampaio Mendonça ${ }^{a}$ \\ ${ }^{a}$ Graduate Program of Biomedical Sciences, Hermínio Ometto University Center, Araras, São Paulo 13607-339, Brazil \\ ${ }^{\mathrm{b}}$ Joint Graduate Program of Graduate Program in Physiological Sciences, Federal University of São Carlos/Paulista \\ State University, São Carlos, São Paulo 13565-905, Brazil \\ ${ }^{\mathrm{c}}$ Graduate Program Cellular and Structural Biology, Campinas State University, UNICAMP, Campinas, São Paulo \\ 13083865, Brazil
}

\section{A R T I C L E I N F O}

Article history:

Accepted 5 April 2017

Keywords:

Phototherapy

Burns

Healing

Rats

\begin{abstract}
A B S T R A C T
Purpose: This study compared different energy densities of laser on second degrees burns in rats aiming to determine the most effective dosimetry in stimulation of the healing process. Methods: Burns were induced in the dorsal skin of 54 animals divided into three groups (n: 18): 1-without treatment; 2-irradiated lesions by the Indium Gallium Phosphide (InGaP) $670 \mathrm{~nm}$ $\left(4.93 \mathrm{~J} / \mathrm{cm}^{2}\right)$ laser; 3-irradiated lesions by the InGaP-670 $\mathrm{nm}\left(9.86 \mathrm{~J} / \mathrm{cm}^{2}\right)$ laser. Samples were collected on the 2, 10 and 18 days after injury for structural, morphometry, biochemical analysis and Western blotting.

Results: The energy densities examined were effective in significantly increasing the total number of fibroblasts and blood vessels and reduce the number of inflammatory cells particularly in irradiated lesions with $9.86 \mathrm{~J} / \mathrm{cm}^{2}$. This same energy density significantly increased the amount of GAGs (Glycosaminoglycans), decreased the TGF- $\beta 1$ (Transforming Growth Factor $\beta 1$ ) and increased the VEGF (Vascular and Endothelial Growth Factor) during the experimental period. This energy density also significantly increased the Collagen type I and decreased Collagen type III and the active isoform of metalloproteinase 9 (MMP-9). Conclusions: The energy density of $9.86 \mathrm{~J} / \mathrm{cm}^{2}$ was more effective in promoting cellular responses related to neoangiogenesis, decreasing inflammation and collagen fibers reorganization.
\end{abstract}

(c) 2017 Elsevier Ltd and ISBI. All rights reserved.

\footnotetext{
* Corresponding author at: Graduate Program of Biomedical Sciences, Hermínio Ometto University Center, UNIARARAS, Avenida Maximiliano Baruto, 500 - Jardim Universitário, Araras, São Paulo, 13607-339, Brazil. Fax: +55 1935431439.

E-mail address: marcelosquisatto@uniararas.br (M.A.M. Esquisatto).

http://dx.doi.org/10.1016/j.burns.2017.04.008

0305-4179/@ 2017 Elsevier Ltd and ISBI. All rights reserved.
} 


\section{Introduction}

Burns produce large local and systemic physiological damage [1] such as the destruction of vascular and capillary integrity, edema formation [2]. The severity of a burn depends on the thermal agent and the contact time with the tissue and it can be evaluated according its depth in the Boyer's rating [3]. Burns result in functional limitations such as decreased body and environment control, as well as aesthetic problems that promote decreased self-esteem, social avoidance, and anxiety about the future [4]. The focus of therapy for burn patients has been of physical and social functionalities [5].

Tissue repair is a process characterized by interrelated events, into sequential phases: inflammatory, proliferative and remodeling under the action of specific cells, cytokines and various growth factors [6]. The TGF- $\beta 1$ (Transforming Growth Factor), especially released in the early stages of this process, is secreted by keratinocytes, fibroblasts and platelets, acting as chemotactic for neutrophils and monocytes at the wound site $[7,8]$. Another important growth factor in tissue repair is VEGF (Vascular and Endothelial Growth Factor) whose secretion is induced by hypoxia and low $\mathrm{pH}$, conditions that stimulate angiogenesis [9]. Metalloproteinases are also involved in the modulation of tissue integrity and modulate the half-life of the molecules of ECM (Extracellular Matrix) by means of selective degradation [10]. GAG (Glycosaminoglycan) and (PGs) Proteoglycans; on the other hand, are involved in proliferation, migration and cell differentiation during tissue repair [11].

The LLLT (low-level laser therapy) is involved in the healing process triggering the photoactivation of cellular mechanisms. Chromophore located in the mitochondria seem to absorb the laser's red and infrared light triggering increased protein synthesis, ATP production, cell proliferation, and reorganization of collagen [12]. The LLLT has stood out among the many therapeutic methods [6,13-15] and has demonstrated in various studies that improves tissue repair as it promotes collagen synthesis and deposition, increased vascularity, inflammation reduction, accelerating the wound remodeling. In this way, it is a promising work tool in the burn wounds therapy [1,8,15-20]. However, its effects are dependent on the different irradiation parameters used such as energy density, wavelength, laser irradiation frequency and duration of treatment [21].

The wavelength of the laser is critical in its absorption by the tissues and their produced physiological effects. Among the therapeutic lasers also known as low-intensity lasers are Helium-Neon (He-Ne), Gallium Arsenide (AsGa), AluminumGallium-Indium-Phosphorus (AlGaInP) and Arsenide-GalliumAluminum (AsGaAl). The wavelengths between 632.8 and $904 \mathrm{~nm}$ are widely used in tissue repair $[2,15,22]$. Two different types of laser (670-InGaP and 830-nm GaAlAs) are used for Chiarotto et al. [8] in the treatment of second-degree burns in rats and it was observed that the laser $670-\mathrm{nm}$ InGaP was more effective in increasing the numbers fibroblast at the injury site. Other authors have also demonstrated the beneficial effects of low intensity laser in tissue repair using 670 $\mathrm{nm}[6,23,24]$.

Thus, this study compared the action of different energy densities of Indium Gallium Phosphide (InGaP) 670 nm laser in second degree burns repair in Wistar rats to identify the best dosimetry to be used in treating this type of injury.

\section{Methods}

\subsection{Animal model}

The experimental procedure was developed using 54 male Wistar rats obtained from Hermínio Ometto University Center (UNIARARAS) - Center of Animal Experimentation. These animals with 120 days with $\pm 300 \mathrm{~g}$ were maintained in individual cages under a 12/12-h light/dark cycle at a constant temperature $\left(23 \pm 2^{\circ} \mathrm{C}\right)$ and humidity $(55 \%)$.

\subsection{Experimental procedure}

In dorsal skin of all animals the burn lesions were induced according the protocol developed by Chiarotto et al. [8]. These were divided into three groups of 18 animals: group 1 , untreated; group 2, lesions irradiated with an InGaP laser at $670 \mathrm{~nm}, 4,93 \mathrm{~J} / \mathrm{cm}^{2}$; group 3, lesions irradiated with an InGaP laser at $670 \mathrm{~nm}, 9,86 \mathrm{~J} / \mathrm{cm}^{2}$. Through anesthetic overdose and cervical dislocation, six animals per group were euthanized in two, ten and eighteen days after experimental injuries for collection of tissue samples and analysis morphometric analysis $(n=3)$, Western blotting, quantitative analysis of glycosaminoglycans, hydroxyproline and zymography to metalloproteinases $(n=3)$. The surgical and experimental procedures received approval by Ethics Committee of the Hermínio Ometto University Center (UNIARARAS) (protocol no. 022/2013) and conducted according with the Guide for the Care and Use of Laboratory Animals [25]. The animals were healthy and procedure did not promote stress.

\subsection{Laser irradiation}

The treatments occurred daily for 18 days according to protocol Chiarotto et al. [8]. For laser therapy was used a Physiolux Dual Bioset ${ }^{\mathbb{B}}$ InGaP laser (Indústria de Tecnologia Eletrônica Ltda., Rio Claro, São Paulo, Brazil) at a wavelength of $670 \mathrm{~nm}$ (visible red), selected in the continuous mode, with an output power of $30 \mathrm{~mW}$, with the beam covering an area of $0.073 \mathrm{~cm}^{2}$, applied for $12 \mathrm{~s}$, energy density of $4,93 \mathrm{~J} / \mathrm{cm}^{2}$ (energy per point of 0.09J, total energy of 0,36J); and for $24 \mathrm{~s}$, energy density of $9,86 \mathrm{~J} / \mathrm{cm}^{2}$ (energy per point of $0.18 \mathrm{~J}$, total energy of $0,72 J)$. The utilization of two energy densities was based on studies performed by Ezzati et al. [16,17], Novaes et al. [26] and Fiório et al. [27] and the different doses and wavelength used in this protocol were chosen according to previous studies used by our research group in burns $[6,14,24]$. For irradiation the apparatus calibration was performed by the manufacturer.

\subsection{Structural and morphometric analysis}

The sample collection ( $25 \mathrm{~mm}$ in diameter) was made following different phases of tissue repair in skin.

After removing, the fragments of tissue were immediately fixed in $10 \%$ formaldehyde in Millonig buffer, $\mathrm{pH} 7.4$, for $24 \mathrm{~h}$ at room temperature. After that, they were washed in buffer 
andsubmitted to routine procedures for embedding in Paraplast $^{\mathrm{TM}}$ (Histosec ${ }^{\circledR}$, Merck). The blocks were cut into 6$\mu \mathrm{m}$ longitudinal sections and stained with Masson's trichrome for collagen fibers quantification in the repaired area (\% area); toluidine blue in McIlvaine buffer ( $\mathrm{pH} 4.0$ ), for histomorphometric analysis of the epidermis and dermis and evaluation of the number of blood vessels and fibroblasts, with Dominici stain for intracellular granules detection in the polymorphonuclear leukocytes [28]. The numbers of newly formed blood vessels, fibroblasts and polymorphonuclear leukocytes $\left(n / 10^{4} \mu \mathrm{m}^{2}\right)$ in the repaired area were determined in longitudinal sections stained [28]. Three samples of $10^{4} \mu \mathrm{m}^{2}$ were made for each of the five sections of each animal per group. The documentation of sections were made on days 2, 10 and 18 of treatment and each sample were captured and digitized in bright field with a Leica DM2000 photomicroscope. For morphometric analysis, samples were examined using the virtual Leica Image Measure ${ }^{\mathrm{TM}}$ grid and Sigma Scan Pro $6.0^{\mathrm{TM}}$ programs [29].

\subsection{Biochemical analysis and Western blotting}

The densitometry values of TGF $\beta 1$, VEGF, Collagen type I and type III signals were developed according to a protocol developed by Jácomo et al. [24] and expressed relative to proteins stained with Ponceau S, which were taken as $100 \%$ [30]. The results were analyzed by ANOVA and the Tukey posttest $(\mathrm{p}<0.05)$ using the GraphPad Prism ${ }^{\mathbb{B}} 3.0$ program.

\subsection{Quantitative analysis of glycosaminoglycans (GAGs)}

The glycosaminoglycans extraction of tissue fragments was made according to the DMMB method [31]. The reading was made in visible spectrophotometer light at $526 \mathrm{~nm}$.

\subsection{Quantification of hydroxyproline (Pro-OH)}

Fragments were weighed, immersed in acetone for $48 \mathrm{~h}$ and then in chloroform: ethanol (2:1) for $48 \mathrm{~h}$. The samples were hydrolyzed in $6 \mathrm{~N} \mathrm{HCl} \mathrm{(} 1 \mathrm{~mL}$ for each $10 \mathrm{mg}$ of tissue) for $16 \mathrm{~h}$ at $110^{\circ} \mathrm{C}$, and neutralized with $6 \mathrm{~N} \mathrm{NaOH}$. For the quantification of total collagen, samples were treated with chloramine $\mathrm{T}$ solution, according to Stegemann and Stalder [32] with some modifications. For the standard curve, HO-Pro concentrations were between 0.2 to $6 \mathrm{mg} / \mathrm{mL}$ using absorbance at $550 \mathrm{~nm}$ in a Spectrophotometer.

\subsection{Molecules extraction from extracellular matrix}

The tissue samples were fractionated with the help of a scalpel blade and fragmented in Polytron ${ }^{\mathbb{B}}$ soaked in saline. After a quick centrifugation, the precipitate was treated with 15 volumes of $50 \mathrm{mM}$ sodium acetate buffer $\mathrm{pH} 5.8$ containing $\mathrm{Gu}-\mathrm{HCl}$ $4 \mathrm{M}$, EDTA $50 \mathrm{mM}$ and PMSF $1 \mathrm{mM}$. The extractions were processed under constant agitation at $4{ }^{\circ} \mathrm{C}$ for $24 \mathrm{~h}$. After the extraction period, the samples were centrifuged at $18,000 \mathrm{rpm}$ for $20 \mathrm{~min}$ at $4^{\circ} \mathrm{C}$ in Beckman centrifuge J2-21 (ROTOR JA-20). After centrifugation, the supernatant (total extract) was used for zymography [33].

\subsection{Zymography to metalloproteinases}

The supernatant from each sample ( $50 \mu$ g protein) was used of according protocol of Silva et al. [34] for the analysis of MMP9 activity.

\subsection{Statistical analysis}

The results of the morphometric analysis, Western blotting and quantitative of Hydroxyproline and GAGs were reported by mean and standard deviation $(\mathrm{X} \pm \mathrm{SD})$ and the values were compared by ANOVA and Tukey's post hoc test $(\mathrm{p}<0.05)$ using software version

\section{Results \\ 3.1. Morphometric analysis}

The number of polymorphonuclear leukocytes in the area of the lesion progressively decreased throughout all the study period when observed the different experimental groups, but in the samples of lesions irradiated with $9.86 \mathrm{~J} / \mathrm{cm}^{2}$ it was observed a significant reduction of these cells in the 18th experimental day relative to the control and to the $4.93 \mathrm{~J} / \mathrm{cm}^{2}$ (Table 1) irradiated lesions.

The quantification of the newly formed vessels increased in the irradiated lesions on the 10th day. But on the 18th day there was an increase only in the $9.86 \mathrm{~J} / \mathrm{cm}^{2}$ (Table 1) irradiated lesions.

Morphometric analysis done on samples taken at the site of injury showed an increase in the total number of fibroblasts in injuries irradiated with $4.93 \mathrm{~J} / \mathrm{cm}^{2}$ and $9.86 \mathrm{~J} / \mathrm{cm}^{2}$ on the 10 th and 18th days compared to those that received no treatment (Table 1). No differences were found when comparing the obtained data from the irradiated lesions between the different doses of energy.

\subsection{Quantification of hydroxyproline and glycosaminoglycans}

In the quantification of GAGs was observed increase on the 18th day experimental in samples from lesions irradiated with energy density of $9.86 \mathrm{~J} / \mathrm{cm}^{2}$ and the hydroxyproline content showed no significant differences between groups throughout all experimental periods (Table 2).

\subsection{Western blotting}

The TGF- $\beta 1$ expression demonstrated through the densitometry revealed that the lesions irradiated with different used energy densities, showed gradual reduction of this growth factor in the different experimental periods compared to the control (Fig. 1). Treatment with the energy density of $9.86 \mathrm{~J} / \mathrm{cm}^{2}$ was significant in this parameter when the data were compared with the energy density of $4.93 \mathrm{~J} / \mathrm{cm}^{2}$ (Fig. 1).

Densitometric analysis of VEGF expression showed an increase of this protein in the lesions irradiated with energy density of $9.86 \mathrm{~J} / \mathrm{cm}^{2}$ throughout the experimental period especially on the 10th day (Fig. 1). 
Table 1-Morphometric parameters evaluated in the repair area of second-degree burns in rats in different treatment groups and experimental periods.

\begin{tabular}{|c|c|c|c|c|}
\hline $\begin{array}{l}\text { Experimental periods } \\
\text { Parameters }\end{array}$ & Groups & $2 d$ & $10 \mathrm{~d}$ & $18 \mathrm{~d}$ \\
\hline \multirow{3}{*}{ Number of granulocytes $\left(n / 10^{4} \mu m^{2}\right)$} & 1 & $46.6 \pm 3.8^{*}$ & $18.2 \pm 2.3^{*}$ & $13.7 \pm 2.9^{*}$ \\
\hline & 2 & $41.4 \pm 2.3$ & $12.7 \pm 2.1$ & $8.2 \pm 2.2$ \\
\hline & 3 & $40.1 \pm 3.4$ & $11.5 \pm 2.5$ & $5.9 \pm 2.3^{*}$ \\
\hline \multirow{3}{*}{ Number of new vessels $\left(n / 10^{4} \mu m^{2}\right)$} & 1 & $1.5 \pm 0.5$ & $2.5 \pm 0.6$ & $3.2 \pm 0.6$ \\
\hline & 2 & $2.1 \pm 0.4$ & $4.6 \pm 0.4^{*}$ & $4.9 \pm 0.4$ \\
\hline & 3 & $1.9 \pm 0.4$ & $4.5 \pm 0.4^{*}$ & $5.3 \pm 0.3^{*}$ \\
\hline \multirow{3}{*}{ Number of fibroblasts $\left(\mathrm{n} / 10^{4} \mu \mathrm{m}^{2}\right)$} & 1 & $103.9 \pm 11.8$ & $216.7 \pm 21.9$ & $231.6 \pm 23.2$ \\
\hline & 2 & $104.3 \pm 10.1$ & $322.1 \pm 28.5^{*}$ & $348.3 \pm 23.3^{*}$ \\
\hline & 3 & $105.2 \pm 10.4$ & $320.2 \pm 24.9^{*}$ & $336.6 \pm 18.3^{*}$ \\
\hline
\end{tabular}

1, Animals not submitted to any treatment; group 2, lesions irradiated with an InGaP laser at $670 \mathrm{~nm}, 4.93 \mathrm{~J} / \mathrm{cm}^{2}$; group 3, lesions irradiated with an InGaP laser at $670 \mathrm{~nm}, 9.86 \mathrm{~J} / \mathrm{cm}^{2}$. Samples were collected from each group 2, 10 and 18 days after injury. Values are the mean and standard deviation of each group and were compared by ANOVA with Tukey's post hoc test $(p<0.05)$. ( $\left.{ }^{*}\right)$ significant difference.

\begin{tabular}{|c|c|c|c|c|}
\hline $\begin{array}{l}\text { Experimental periods } \\
\text { Parameters }\end{array}$ & Groups & $2 d$ & $10 \mathrm{~d}$ & $18 \mathrm{~d}$ \\
\hline \multirow[t]{3}{*}{ Glycosaminoglycans ( $\mu \mathrm{g} / \mathrm{mg}$ of dry tissue) } & 1 & $1.08 \pm 0.18$ & $1.35 \pm 0.15$ & $1.37 \pm 0.14$ \\
\hline & 2 & $1.22 \pm 0.12$ & $1.45 \pm 0.18$ & $1.89 \pm 0.17$ \\
\hline & 3 & $1.26 \pm 0.13$ & $1.58 \pm 0.14$ & $2.86 \pm 0.14^{*}$ \\
\hline \multirow[t]{3}{*}{ Hydroxyproline ( $\mu \mathrm{g} / \mathrm{mg}$ of dry tissue) } & 1 & $135.4 \pm 16.2$ & $128.4 \pm 17.4$ & $128.9 \pm 12.6$ \\
\hline & 2 & $150.2 \pm 15.4$ & $148.6 \pm 17.9$ & $146.7 \pm 13.8$ \\
\hline & 3 & $159.9 \pm 18.1$ & $157.1 \pm 12.2$ & $153.5 \pm 13.4$ \\
\hline
\end{tabular}

1, Animals not submitted to any treatment; group 2, lesions irradiated with an InGaP laser at $670 \mathrm{~nm}, 4.93 \mathrm{~J} / \mathrm{cm}^{2}$; group 3, lesions irradiated with an InGaP laser at $670 \mathrm{~nm}, 9.86 \mathrm{~J} / \mathrm{cm}^{2}$. Samples were collected from each group 2, 10 and 18 days after injury. Values are the mean and standard deviation of each group and were compared by ANOVA with Tukey's post hoc test $(\mathrm{p}<0.05)$. (*) significant difference.

As for Collagen, the analyzes of the data showed a decrease in the expression of type III and an increase on type I over the study period, especially in lesions irradiated with energy density of $9.86 \mathrm{~J} / \mathrm{cm}^{2}$, compared to other groups (Fig. 1).

\subsection{Zymography}

Zymography for MMP-9 (Fig. 2) detected the latent and active isoform at all times and experimental groups, and were observed significantly higher values compared to the control in the irradiated lesions. However, a gradual decrease of the active isoform was observed from the 2nd to the 18th experimental day in the irradiated groups, with highlighted on the energy density of $9.86 \mathrm{~J} / \mathrm{cm}^{2}$.

\section{Discussion}

The purpose of this study was to compare different energy densities during the repair process in its different phases: inflammation (2nd day), granulation tissue formation and reepithelialization (10th and 18th days). All phases of tissue repair process are affected positively with the LLLT and the choice of wavelength and energy density are crucial to a successful treatment [35]. The energy per point also is important in the application of laser because it the time of tissue exposure and the output power improvement the study reproducibility [36]. Ezzati et al. [16] have compared two types of energy density $\left(2.3-11.7 \mathrm{~J} / \mathrm{cm}^{2}\right)$ in the treatment of second degree burns in mice and observed that the irradiation fluence of $11.7 \mathrm{~J} / \mathrm{cm}^{2}$ significantly favored the repair of wounds. The application of different energy densities $\left(3\right.$ and $30 \mathrm{~J} / \mathrm{cm}^{2}$ ) on excisional wounds in Wistar rats resulted in increased tissue cellularity, angiogenesis, collagen fibers and glycosaminoglycans synthesis, especially when using a density of $30 \mathrm{~J} / \mathrm{cm}^{2}$ [26].

The quantitative analysis revealed in this study a decrease in the number of polymorphonuclear leukocytes, mainly present during the inflammatory phase (day 2), in samples of the irradiated burns particularly with $9.86 \mathrm{~J} / \mathrm{cm}^{2}$ indicating that the choice of the energy density is necessary to the treatment success [35]. LLLT, as stated in many experimental investigations, has beneficial effects on the reduction of cells involved in the inflammatory infiltrate [6,14] Chiarotto et al. [8] compared two kinds of laser $\left(670-\mathrm{nm}\right.$ InGaP $-4.93 \mathrm{~J} / \mathrm{cm}^{2}$ and $830-\mathrm{nm} \mathrm{GaAlAs}-4.48 \mathrm{~J} / \mathrm{cm}^{2}$ ) in the treatment of second degree burns and observed that both significantly reduced the 

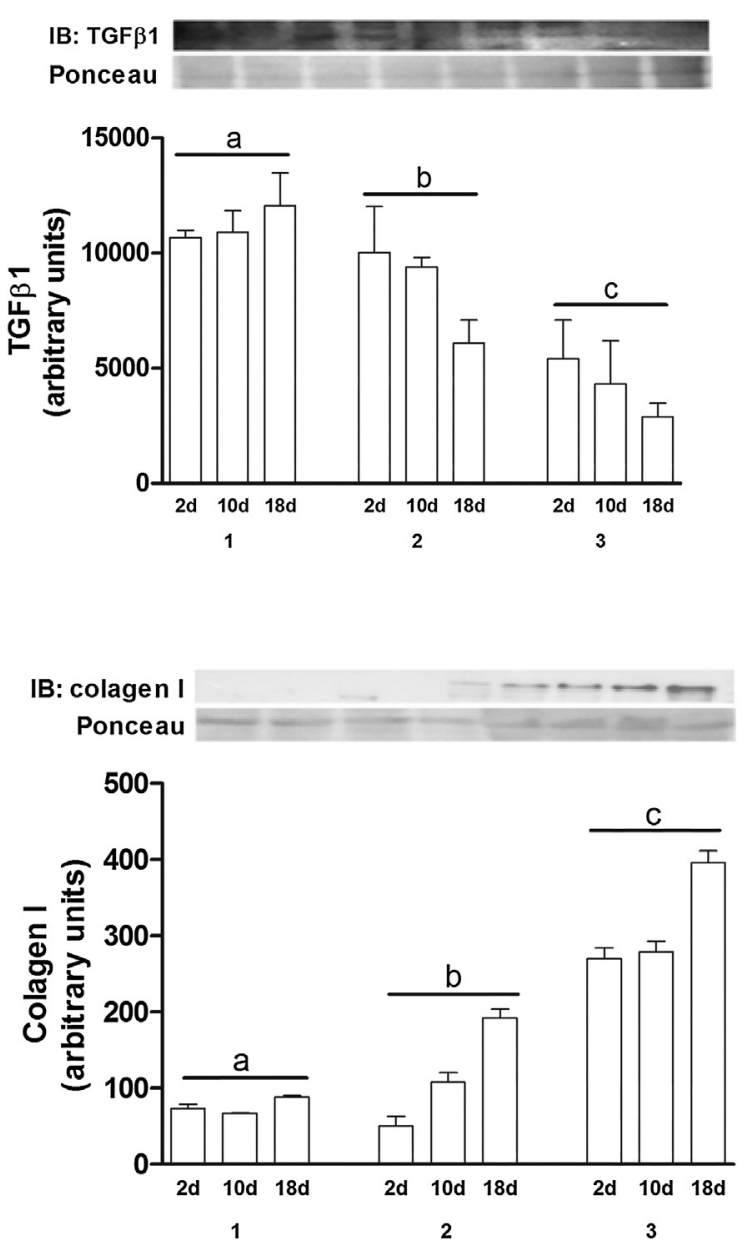

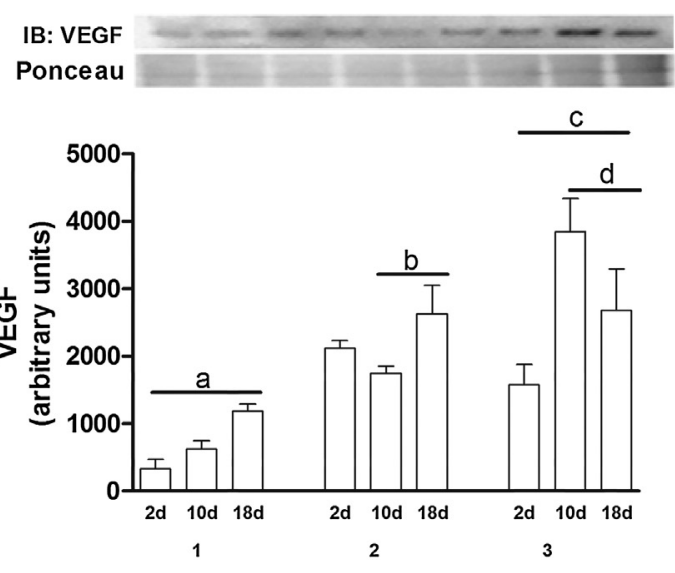

IB: colagen III Ponceau

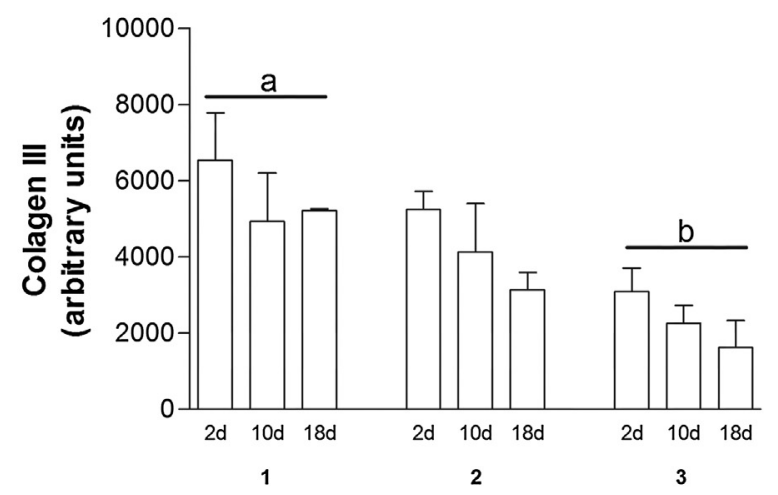

Fig. 1 - Immunoblotting (IB) of the protein expression of TGF- $\beta 1$ (A), VEGF (B), Collagen type I (C) and type III (D) in the area of the burn in the dorsal skin of rats in the different experimental groups. 1, animals not submitted to any treatment; group 2, lesions irradiated with an InGaP laser at $670 \mathrm{~nm}, 4.93 \mathrm{~J} / \mathrm{cm}^{2}$; group 3, lesions irradiated with an InGaP laser at $670 \mathrm{~nm}, 9.86 \mathrm{~J} / \mathrm{cm}^{2}$. Samples were collected from each group 2, 10 and 18 days after injury. Typical blots are shown above the average of densitometry. Data are presented as mean and standard deviation for each group. The values were compared using ANOVA with Tukey's post hoc test $(p<0.05)$. The letters indicate significant differences for each graph: TGF-B1, Collagen type I: a vs. $b$ and c vs. b; VEGF: a vs. $b$ and c vs. $d$; Collagen type III: $a$ vs. $b$.

number of polymorphonuclear leukocytes in the repair process. Silveira et al. [37] also observed a reduction in the area of excisional wounds comparing different wavelengths and irradiation doses (HeNe laser, $904 \mathrm{~nm}$ and $\mathrm{GaAs}, 660 \mathrm{~nm}$ and energy density of $1 \mathrm{~J} / \mathrm{cm}^{2}, 3 \mathrm{~J} / \mathrm{cm}^{2}$ on both) and observed beneficial effects of both laser types used in different doses, since it induced collagen synthesis and reduced inflammatory phase.

The decreased TGF- $\beta 1$ expression during the experimental period also aims to reduce the inflammatory process in the irradiated lesions, since the presence this protein is important in the early stages of the tissue repair process recruiting leukocytes in site of lesion inducing inflammation $[7,38]$. In this phase also occurs the important participation of some gelatinases like MMP-9, which is found in the granules of neutrophils and macrophages, and is often released at the site of the lesion [39]. Studies have observed that there is a dosedependent relationship between expression of TGF- $\beta 1$ and MMP-9 [40,41]. Hsieh et al. [42] showed that this growth factor induces the expression of MMP-9, which probably explains the results found in our study where we observed gradual reduction of gelatinase expression and of TGF- $\beta 1$, especially for samples submitted to treatment with energy density 9.86J/ $\mathrm{cm}^{2}$ demonstrating that this one was more effective in reducing the inflammatory process in the last stages of the trial period. The MMP-9 plays an important facilitating role in the events observed during the inflammatory process [43]. Reiss et al. [44] considered that the excessive and prolonged production of MMP-9 leads to a disturbance in wound repair, but if this metalloproteinase is inhibited to epithelialization is impaired which highlights its modulating role in the homeostasis of tissue repair.

Comparison of the irradiation of lesions with different energy densities showed that especially the energy density energy density $9.86 \mathrm{~J} / \mathrm{cm}^{2}$ caused an increase in newly formed vessels in the 10th and 18th experimental days (proliferative phase). Corazza et al. [45] compared the angiogenic effects of LLLT $\left(5 \mathrm{~J} / \mathrm{cm}^{2}\right.$ and $\left.20 \mathrm{~J} / \mathrm{cm}^{2}\right)$ and the LED (Light-emitting diode) 
(A)

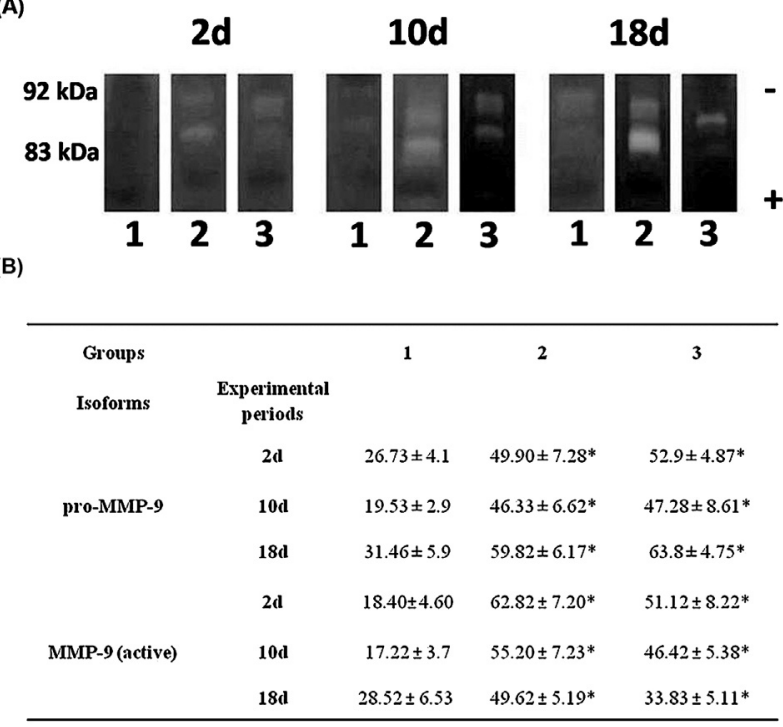

Fig. 2 - (A) Zymogram for analyzing the isoforms latent $(92 \mathrm{kDa})$ and active $(83 \mathrm{kDa})$ of MMP-9 in the wound healing process of second-degree burns in rats diabetics in different treatment groups and experimental periods. (B) Densitometry of the bands (pixels) corresponding to the latent isoforms $(92 \mathrm{kDa})$ and active $(83 \mathrm{kDa})$ of MMP-9 in the wound healing process of second-degree burns in rats diabetics in different treatment groups and experimental periods ( $n=3 /$ group/ time). Group 1, animals not submitted to any treatment; group 2, lesions irradiated with an InGaP laser at $670 \mathrm{~nm}$, $4.93 \mathrm{~J} / \mathrm{cm}^{2}$; group 3 , lesions irradiated with an InGaP laser at $670 \mathrm{~nm}, 9.86 \mathrm{~J} / \mathrm{cm}^{2}$. Samples were collected from each group 2 , 10 and 18 days after injury. Values are the mean and standard deviation $\left(\mathrm{x}^{3} 0^{3}\right)$ of each group and were compared by ANOVA with Tukey's post hoc test $(p<0.05)$. ( $\left.{ }^{*}\right)$ significant difference.

$\left(5 \mathrm{~J} / \mathrm{cm}^{2}\right.$ and $\left.20 \mathrm{~J} / \mathrm{cm} 2\right)$ in the treatment of induced wounds in Wistar rats and they observed that the energy density of $5 \mathrm{~J} / \mathrm{cm}^{2}$ was more effective in promoting formation of new vessels. Other authors have also shown that LLLT improves microcirculation and angiogenesis at the site of injury $[6,8,14]$. In our study, it was also observed an increase of VEGF expression in irradiated lesions compared to control in last experimental periods. However, radiated lesions with energy density of $9.86 \mathrm{~J} / \mathrm{cm}^{2}$ showed an increase in the expression of this growth factor mainly on the 10th day indicating that this dose of energy was more effective in this parameter. The decrease on day 18th in the same dose of energy indicates the formation of new vessels since VEGF is also stimulated when the cells are subjected to hypoxia $[46,47]$.

Quantitative analysis of samples irradiated in different energy density used in our study showed that both increased of fibroblasts in the last experimental periods studied. (proliferative phase) Chiarotto et al. [8] also observed it when used the laser $670 \mathrm{~nm}$ InGaP, $4.93 \mathrm{~J} / \mathrm{cm}^{2}$ in second degree burns. Silveira et al. [37] considered that the increase of collagen observed in irradiated excising lesions, especially in $3 \mathrm{~J} / \mathrm{cm}^{2}$ in rats was a consequence of the acceleration of the processes of migration and proliferation of fibroblasts induced by this treatment. Regarding collagen fibers our results indicate a growing reorganization of the same as it was a progressive decrease of Collagen type III and increase on Collagen type I in the irradiated injuries. In both it was detected a significant difference in the samples treated with energy density of $9.86 \mathrm{~J} / \mathrm{cm}^{2}$. The evaluation of these two types of collagen have been an important indicator in the progression of the repair process and that in the early stages predominates the synthesis of Collagen type III which is gradually replaced by Collagen type I [48-50]. It is widely recognized that therapies that stimulate the synthesis of Collagen type I lead to increased collagen maturation and are used due course in wound care [51,52].

Regarding the concentration of hydroxyproline, an important indicator of synthesis and deposition of collagen fibers [53], the data analyzed showed increasing during the experimental period in the irradiated lesions compared to nonirradiated lesions, although these have not shown significant differences between the experimental groups.

The glycosaminoglycan content observed in our study demonstrated the significant influence of photobiostimulation energy density of $9.86 \mathrm{~J} / \mathrm{cm}^{2}$. This result is relevant since the GAGs are involved in the development of an important functional and structural support migration and cell differentiation [54].

The results found in this study corroborate with the literature that indicates that low intensity laser therapy can be used in clinical practice. These lasers do not deliver enough power to damage tissue, but they do deliver enough energy to stimulate tissue repair [55]. It also contributed to add that the therapy with energy density $9.86 \mathrm{~J} / \mathrm{cm} 2$ is effective in the treatment of second degree burns.

\section{Conclusion}

The different energy densities of InGaP-670nm laser studied promoted beneficial biomodulators effects on the repair burns in this experimental model, as promoted neoangiogenesis, decreased inflammation and reorganization of collagen fibers. The energy density of $9.86 \mathrm{~J} / \mathrm{cm}^{2}$ was more effective in promoting cellular responses related to these parameters. Thus, burns being a worldwide public health problem, it is important that further investigation in the search of a dose, wavelength and treatment duration ideal in use of LLLT in the therapy of this type of lesions gets done.

\section{Conflict of interest}

We declare that no conflict of interest in this study.

\section{Authors participation}

Luis Angelo Ozan Maligieri - acquisition and interpretation of data, involved in technical procedures.

Lia Mara Grosso Neves - acquisition and interpretation of data, involved in technical procedures. 
Andrea Aparecida de Aro - acquisition and interpretation of data from analytical procedures.

Edson Rosa Pimentel - acquisition and interpretation of data from analytical procedures.

Maria Esméria Corezola do Amaral - acquisition and interpretation of data and Western blotting analysis.

Marcelo Augusto Marretto Esquisatto - acquisition and interpretation of data, histomorphometric analysis and critical revision.

Gláucia Maria Tech dos Santos - supervised all phases of the study, manuscript writing and critical revision.

Fernanda Aparecida Sampaio Mendonça - main author. Tutor, responsible for conception, design, intellectual and scientific content of the study; critical analysis; final approval of manuscript.

\section{Acknowledgment}

The authors thank the Hermínio Omettto Foundation (Araras, São Paulo, Brazil) for financial support.

\section{REF E R E N C E S}

[1] Bayat M, Vasheghani MM, Razavi N, Taheri S, Rakhshan M. Effect of low-level laser therapy on the healing of seconddegree burns in rats: a histological and microbiological study. J Photochem Photobiol B 2005;78:171-7.

[2] Carvalho PTC, Silva IS, Reis FA, Perreira DM, Aydos RD. Influence of InGaAlP laser $(660 \mathrm{~nm})$ on the healing of skin wounds in diabetic rats. Acta Cir Bras 2010;25:71-9.

[3] Benaim F. Burn classification according to skin depth; necessity to adopt a uniform criterion. Rev Argent Quemad 1991;6:22-6.

[4] Knight A, Wasiak J, Salway J, O'Brien L. Factors predicting health status and recovery of hand function after hand burns in the second year after hospital discharge. Burns 2017; 43:100-6.

[5] Lin SY, Chang JK, Chen PC, Mao HF. Hand function measures for burn patients: a literature review. Burns 2013;39:16-23.

[6] Belli M, Fernandes CR, Neves LMG, Mourão V, Barbieri R, Esquisatto MAM, Amaral MEC, Santos GMT, Mendonça FAS. Application of $670 \mathrm{~nm}$ InGaP laser and microcurrent favors the healing of second-degree burns in Wistar rats. Laser Phys 2015;25:025602.

[7] Atkins S, Smith KG, Loescher AR, Boissonade FM, Ferguson MW, Robinson PP. The effect of antibodies to TGF-beta 1 and TGF-beta 2 at a site of sciatic nerve repair. J Peripher Nerv Syst 2006;11:286-93.

[8] Chiarotto GB, Neves LM, Esquisatto MA, do Amaral ME, dos Santos GMT, Mendonça FAS. Effects of laser irradiation (670$\mathrm{nm}$ InGaP and 830-nm GaAlAs) on burn of second-degree in rats. Lasers Med Sci 2014;29:1685-93.

[9] Werner S, Grose R. Regulation of wound healing by growth factors and cytokines. Physiol Rev 2003;83:835-70.

[10] Martins VL, Calley M, O'Toole EA. Matrix metalloproteinases and epidermal wound repair. Cell Tissue Res 2013;351:255-68.

[11] Ponrasu T, Suguna L. Efficacy of Annona squamosa L in the synthesis of glycosaminoglycans and collagen during wound repair in streptozotocin induced diabetic rats. Biomed Res Int 2014;2014:1-10 Article ID 124352.

[12] Karu TI. Low power laser therapy. Biomedical photonics handbook 200348:. p. 1-48.
[13] Bayat M, Azari A, Golmohammadi MG. Effects of 780-nm lowlevel laser therapy with a pulsed gallium aluminum arsenide laser on the healing of a surgically induced open skin wound of rat. Photomed Laser Surg 2010;28:465-70.

[14] Catarino HR, de Godoy NP, Scharlack NK, Neves LM, de Gaspi FO, Esquisatto MA, do Amaral ME, Mendonça FA, dos Santos GMT. InGaP 670-nm laser therapy combined with a hydroalcoholic extract of Solidago chilensis Meyen in burn injuries. Lasers Med Sci 2015;30:1069-79.

[15] Loreti EH, Pascoal VL, Nogueira BV, Silva IV, Pedrosa DF. Use of laser therapy in the healing process: a literature review. Photomed Laser Surg 2015;33:104-16.

[16] Ezzati A, Bayat M, Taheri S, Mohsenifar Z. Low-level laser therapy with pulsed infrared laser accelerates third-degree burn healing process in rats. J Rehabil Res Dev 2009;46:543-54.

[17] Ezzati A, Bayat M, Khoshvaghti A. Low-level laser therapy with a pulsed infrared laser accelerates second-degree burn healing in rat: a clinical and microbiologic study. Photomed Laser Surg 2010;28:603-11.

[18] Khoshvaghti A, Zibamanzarmofrad M, Bayat M. Effect of lowlevel treatment with an $80-\mathrm{Hz}$ pulsed infrared diode laser on mat-cell numbers and degranulation in a rat model of thirddegree burn. Photomed Laser Surg 2011;29:597-604.

[19] Vasheghani MM, Bayat M, Dadpay M, Habibie M, Rezaei F. Lowlevel laser therapy using 80-Hz pulsed infrared diode laser accelerates third-degree burn healing in rat. Photomed Laser Surg 2009;27:959-64.

[20] Núñez SC, França CM, Silva DF, Nogueira GE, Prates RA, Ribeiro MS. The influence of red laser irradiation timeline on burn healing in rats. Lasers Surg Med 2013;28:633-41.

[21] Woodruff LD, Bounkeo JM, Brannon WM, Dawes KS, Barham CD, Waddell DL, Enwemeka CS. The efficacy of laser therapy in wound repair: a meta-analysis of the literature. Photomed Laser Surg 2004;22:241-7.

[22] Hawkins D, Abrahamse H. Biological effects of helium-neon laser irradiation on normal and wounded human skin fibroblasts. Photomed Laser Surg 2005;23:251-9.

[23] Neves LMG, Matheus RL, Santos GMT, Esquisatto MAM, Amaral MEC, Mendonça FAS. Effects of microcurrent application and $670 \mathrm{~nm}$ InGaP lowlevel laser irradiation on experimental wound healing in healthy and diabetic Wistar rats. Laser Phys 2013;23:035604.

[24] Jácomo AC, de Andrade Velozo K, Lotti RG, Neves LM, de Gaspari de Gaspi FO, Esquisatto MAM, do Amaral MEC, Mendonça FAS, dos Santos GMT. Activity of Porophyllum ruderale leaf extract and 670-nm InGaP laser during burns repair in rats. BMC Complement Altern Med 2015;15:274.

[25] Institute for laboratory animal research, guide for the care, and use of laboratory animals. Washington, DC: National Academies Press; 2011.

[26] Novaes RD, Gonçalves RV, Cupertino MC, Araújo BM, Rezende RM, Santos EC, Leite JPV, Matta SLP. The energy density of laser light differentially modulates the skin morphological reorganization in a murine model of healing by secondary intention. Int J Exp Pathol 2014;95:138-46.

[27] Fiório FB, Albertini R, Leal-Junior EC, de Carvalho PT. Effect of low-level laser therapy on types I and III collagen and inflammatory cells in rats with induced third-degree burn. Lasers Med Sci 2014;29:313-9.

[28] Dominici H. Polynuclearis macrophages. Arch Med Exp 1902;14:1

[29] Miller Jr RG. Simultaneous statistical inference. New York: Springer-Verlag: Berlin Heidelberg; 1981 p. 301.

[30] Towbin H, Staehelin T, Gordon J. Electrophoretic transfer of proteins from polyacrylamide gels to nitrocellulose sheets: procedure and some applications. Proc Natl Acad Sci U S A 1979;76:4350-4.

[31] Farndale RW, Buttle DJ, Barrett AJ. Improved quantitation and discrimination of sulphated glycosaminoglycans by use of 
dimethylmethylene blue. Biochim Biophys Acta 1986; 883:173-7.

[32] Stegemann H, Stalder K. Determination of hydroxyproline. Clin Chim Acta 1967;18:267-73.

[33] Vogel KG, Heinegård D. Characterization of proteoglycans from adult bovine tendon. J Biol Chem 1985;260:9298-306.

[34] Silva JA, Lorencini M, Peroni LA, De La Hoz CL, Carvalho HF, Stach-Machado DR. The influence of type I diabetes mellitus on the expression and activity of gelatinases (matrix metalloproteinases-2 and -9) in induced periodontal disease. J Periodontal Res 2008;43:48-54.

[35] Enwemeka CS, Parker JC, Dowdy DS, Harkness EE, Sanford LE, Woodruff LD. The efficacy of low-power lasers in tissue repair and pain control: a meta-analysis study. Photomed Laser Surg 2004;22:323-9.

[36] Wagner VP, Meurer L, Martins MA, Danilevicz CK, Magnusson AS, Marques MM, Filho MS, Squarize CH, Martins MD. Influence of different energy densities of laser phototherapy on oral wound healing. J Biomed Opt 2013;18:128002.

[37] Silveira PC, Silva LA, Freitas TP, Latini A, Pinho RA. Effects of low power laser irradiation (LPLI) at different wavelengths and doses on oxidative stress and fibrogenesis parameters in an animal model of wound healing. Lasers Med Sci 2011; 26:125-31.

[38] Guo S, Dipietro LA. Factors affecting wound healing. J Dent Res 2010;89:219-29.

[39] Araújo RVS, Silva FO, Melo-Junior MR, Porto ALF. Metalloproteinases: systemic physio-pathological aspects and its importance in the wound healing. Rev Ciênc Méd Biol 2011;10:82-8.

[40] Gomes LR, Terra LF, Wailemann RA, Labriola L, Sogayar MC. TGF- $\beta 1$ modulates the homeostasis between MMPs and MMP inhibitors through p38 MAPK and ERK1/2 in highly invasive breast cancer cells. BMC Cancer 2012;12:26.

[41] Kim HS, Luo L, Pflugfelder SC, Li DQ. Doxycycline inhibits TGFbeta1-induced MMP-9 via Smad and MAPK pathways in human corneal epithelial cells. Invest Ophthalmol Vis Sci 2005; 46:840-8.

[42] Hsieh HL, Wang HH, Wu WB, Chu PJ, Yang CM. Transforming growth factor- $\beta 1$ induces matrix metalloproteinase- 9 and cell migration in astrocytes: roles of ROS-dependent ERK- and JNKNF-B pathways. J Neuroinflamm 2010;7:88.

[43] Wall SJ, Bevan D, Thomas DW, Harding KG, Edwards DR, Murphy G. Differential expression of matrix metalloproteinases during impaired wound healing of the diabetes mouse. J Invest Dermatol 2002;119:91-8.

[44] Reiss MJ, Han YP, Garcia E, Goldberg M, Yu H, Garner WL. Matrix metalloproteinase-9 delays wound healing in a murine wound model. Surgery 2010;147:295-302.

[45] Corazza AV, Jorge J, Kurachi C, Bagnato VS.

Photobiomodulation on the angiogenesis of skin wounds in rats using different light sources. Photomed Laser Surg 2007;25:102-6.

[46] Hoeben A, Landuyt B, Highley MS, Wildiers H, Van Oosterom AT, De Bruijn EA. Vascular endothelial growth factor and angiogenesis. Pharmacol Rev 2004;56:549-80.

[47] Bao P, Kodra A, Tomic-Canic M, Golinko MS, Ehrlich HP, Brem $\mathrm{H}$. The role of vascular endothelial growth factor in wound healing. J Surg Res 2009;153:347-58.

[48] Karu TI, Kolyakov SF. Exact action spectra for cellular responses relevant to phototherapy. Photomed Laser Surg 2005;23:355-61.

[49] Gonçalves RV, Mezêncio JM, Benevides GP, Matta SL, Neves CA, Sarandy MM, Vilela EF. Effect of gallium-arsenide laser, gallium-aluminum-arsenide laser and healing ointment on cutaneous wound healing in Wistar rats. Braz J Med Biol Res 2010;43:350-5.

[50] Medrado AR, Pugliese LS, Reis SR, Andrade ZA. Influence of low level laser therapy on wound healing and its biological action upon myofibroblasts. Lasers Surg Med 2003;32:239-44.

[51] Pugliese LS, Medrado AP, Reis SR, Andrade Z, de A. The influence of low-level laser therapy on biomodulation of collagen and elastic fibers. Pesqui Odontol Bras 2003;17:307-13.

[52] Nayak SB, Pinto Pereira L, Maharaj D. Wound healing activity of Carica papaya L. in experimentally induced diabetic rats. Indian J Exp Biol 2007;45:739-43.

[53] Hodde J. Naturally occurring scaffolds for soft tissue repair and regeneration. Tissue Eng 2002;8:295-308.

[54] Lai PH, Chang Y, Chen SC, Wang CC, Liang HC, Chang WC, Sung HW. Acellular biological tissues containing inherent glycosaminoglycans for loading basic fibroblast growth factor promotes angiogenesis and tissue regeneration. Tissue Eng 2006;12:2499-508.

[55] Hawkins D, Houreld N, Abrahamse H. Low level laser therapy (LLLT) as an effective therapeutic modality for delayed wound healing. Ann N Y Acad Sci 2005;1056:486-93. 